\title{
Children's use of Bahasa Indonesia in Jakarta kindergartens
}

\author{
BERNADETTE KUSHARTANTI, \\ HANS VAN DE VELDE, AND MARTIN EVERAERT
}

\begin{abstract}
At a very young age children living in Jakarta use both Colloquial Jakarta Indonesia and Bahasa Indonesia. The children's first and most used language is Colloquial Jakarta Indonesia. In the formal school setting Bahasa Indonesia is frequently used and stimulated on a daily basis, and the learning process of Bahasa Indonesia is accelerated. The question addressed in this article is: how do these children choose from their repertoire of language varieties at this stage of language development? In our study 63 children (aged three to five), were interviewed in a formal and an informal situation in three playgroups and kindergartens. This study shows that even in the preschool setting, young children are already developing their sociolinguistic competence, knowing when to choose which language variety.

KEYWORDS

Preschoolers, language development, sociolinguistic competence, Indonesian varieties, Jakarta.
\end{abstract}

\section{INTRODUCTION ${ }^{1}$}

In school settings we expect that children - even when just enrolled to school - master already some norms of social interaction, such as "good" rules of turn-taking or language choice: "Even in the very first tasks children engage in at school, the expectation is that they will adopt a stance that presents them as experts who can provide information that is structured in conventional ways" (Schleppegrell 2001: 433). Kindergartens or preschools in Jakarta are no exceptions. When the new preschoolers meet the teachers, even for the very first time, they already have to understand the importance of using the

1 This article is dedicated to Hein Steinhauer. The content of this article is partly based on the study on the acquisition of Indonesian varieties by Jakarta children (see Kushartanti 2014a).

The authors may be reached at: kushartanti.hum@ui.ac.id (BERNADETTE KUSHARTANTI), hvandevelde@fryske-akademy.nl (HANS VAN DE VELDE), m.b.h.everaert@uu.nl (MARTIN EVERAERT). More information about authors can be found at the end of the article.

(C) 2015 Faculty of Humanities, University of Indonesia

DOI: 10.17510/wjhi.v16i1.371 
right way to address, to greet, or to answer the questions.

At home, where they are taught how to behave socially and verbally, today's Jakarta children generally acquire Colloquial Jakarta Indonesian (CJI) ${ }^{2}$ as their first language. CJI is an informal variety of Indonesian, which is used in daily conversation. Generally they learn Bahasa Indonesia (BI), the formal variety of Indonesia, later. BI is mainly used for story-telling and it is the language variety they frequently hear on television. When children are enrolled to preschool, they are, therefore, already familiar with both varieties. Nevertheless, at school - an institution in which formality is more standard - the use of Bahasa Indonesia is more favored. In this article we address the question how these children use these varieties in the preschool setting.

This article highlights part of a study on the acquisition of Indonesian varieties by Jakarta Indonesian children, aged three to five (Kushartanti 2014a). The study involved Jakarta preschoolers from middle-class families who attend playgroups and kindergartens located in South Jakarta, Depok, and Tangerang. Three schools - one Catholic, one Islamic, and one public participated. The data in this study are obtained from interviews that elicited the children's use of the morphology of BI and CJI verbs. Our focus in this article is merely on the development of the use of BI by these children.

In Section 1 we sketch the sociolinguistic environment of children from middle class families in Jakarta. The research methods are described in Section 2. In Section 3 we present the children's overall use of BI and CJI during the interviews. In Section 4 we will look into more detail in the factors that influence the children's use of BI verbal morphology. Large individual differences in the children's development of the use of BI verbs show up, and we will provide explanations for at first sight contradictory results in Section 5. A conclusion is presented in Section 6.

\section{THE SOCIOLINGUISTIC ENVIRONMENT OF CHILDREN FROM MIDDLE CLASS FAMILIES IN JAKARTA}

First, a brief description of the sociolinguistic situation in Jakarta is presented. Second, some background information on language learning at home and at school for children from middle class families in Jakarta is given.

\subsection{THE SOCIOLINGUISTIC SITUATION IN JAKARTA}

Jakarta is a city with a complex linguistic situation; it is a multi-ethnic and multilingual city. As in many places of the country, Indonesian is mainly used as the lingua franca among the residents. The use of regional languages in intraethnic communication still exists, as there are people from various regions of Indonesia coming and living there. The use of foreign languages among educated speakers, especially English, is increasing today. Each language has their respective function in the society.

2 Several names are used to refer to this variety: spoken Jakarta Indonesian (Wouk 1989), spoken Indonesian (Gunarwan 1984), or Colloquial Jakarta Indonesian (Sneddon 2006). In this article we employ the latter, as it represents both spoken and written forms. 
There are (at least) two varieties of Indonesian playing an important role. The formal variety is Bahasa Indonesia (BI), which is mainly used in writing. It has been propagated as a national language (see Sneddon 2003; Kridalaksana 2010), ratified by the government in the 1945 Constitution. It is the language used in administration and in the national news media. BI is also used as the language of education and taught as the main subject in formal schooling, from elementary school to high school. Proficiency in BI indicates the level of education one has acquired (see also Tilden 1985; Sneddon, 2003, 2004, 2006). The informal variety is Colloquial Jakarta Indonesian (CJI) or Bahasa Indonesia Jakarta, which is mainly used in spoken form, and mostly in casual speech or semi-formal situations. Nowadays it is also used in other big cities of Indonesia, due to the influence of the media, especially television and radio (mainly entertainment and news), youth urban magazines, and popular songs (Purwo 1997; Sneddon 2003, 2006), showing its prestige (see also Oetomo 1990). As CJI and BI have their respective functions in Indonesia, we can say that both are regarded as prestigious varieties in Jakarta (see also Smith-Hefner 2007 for the prestige of colloquial Indonesian among young generations in Java, and Arka 2013 for the prestige of BI in Indonesia).

The language of the native inhabitants of Jakarta, Betawi Malay, is still used in daily conversation by people in the outskirts of Jakarta. For some, it is stigmatized as a lower-class variety (Grijns 1981; Sneddon 2006; Kushartanti et al. 2010; Kushartanti 2014a-b; however, see also Muhadjir 2000). Some linguistics characteristics of CJI originate in Betawi Malay (Wouk 1989; Sneddon 2006).

The largest ethnic group in Jakarta is the Javanese, followed by the Sundanese. There are other ethnic groups from Sumatra (Acehnese, Batak, Minangkabau, and Palembang), and from other islands such as Maluku (Ambonese), Nusa Tenggara (Flores and Bima), and Sulawesi (Manadonese, Bugis, Makasar, and Toraja). Another large ethnic group are the Chinese descendants, of whom some use the Hakka language within their community. There is also a small minority of people of Arab and Indian descent. In all these cases some people still maintain the language (or dialect) of their origin in their own community. However, the use of these languages is decreasing nowadays. Some still use their heritage language in specific situations (for example, the use of kinship terms or ceremonial terms), but especially the younger generation opts for Indonesian. Many also use foreign languages, especially English, which is also one of the main subjects at school. Proficiency in English is an advantage on the job market (see also Lauder 2008). Indonesian-English codeswitching and borrowings from English show up in both spoken and written forms (see for example Sneddon 2006 and Da Silva 2013).

\subsection{LANGUAGE INPUT AND LANGUAGE LEARNING FROM HOME AND AT SCHOOL}

Inter-ethnic marriages are commonly found in Jakarta. Many families opt for Indonesian as the main language at home when they talk to their children, 
though their own language of origin is still used to some extent. Nababan (1992) already showed that parents - both from inter-ethnic and intra-ethnic marriages - choose Indonesian as the language at home. The reason is, among others, that the main medium for instruction is Indonesian. Nowadays Indonesian has become the first language for many of Jakarta children.

Besides the core family, there are sometimes additional members in these households like grandparents and other relatives. Furthermore, the majority of middle-class families hire nannies or servants to take care of the children. While parents are away they take care of the children. Often they spend more time with the children than the working parents do. ${ }^{3}$ As such they are the main source of children's social learning process, including learning how to behave verbally. This means that the linguistic input may come from various sources. It is common that grand parents still use their native heritage language in the presence of children, and, therefore, children may learn a regional language from them. Nannies or servants, who in majority come from Java, also may maintain their own regional language (Javanese and Sundanese) in interaction among their peers. Yet, the use of CJI is also common when they speak to others, as well as to the children, because being newcomers in Jakarta they strive to be fluent in the dominant variety (see also Oetomo 1990).

Wouk $(1989,1999)$ observed that generally Jakarta children acquire the informal variety of Indonesian as their first language. It is the language that the family members used most in daily conversations. In general, BI is acquired later, when children start going to school, but it has been observed that children begin to learn BI at home earlier as well (Kushartanti et al. 2010). Parents consider learning BI at very young age to be important and, therefore, will commonly use BI for story telling. Some even claim that they use BI in many conditions and situations in interaction with their children, such as showing their anger, reprimanding, admonishing or explaining.

Children are systematically exposed to BI when they go to school. From elementary to high school, children are taught BI as a main subject. It is used (generally) as the main medium of instruction, both spoken and written. ${ }^{4}$ However, BI among the students - as well as Sundanese that is taught in Depok, Bekasi, or Tangerang as a subject - is seldom used.

Young children are used to engage in conversations in both varieties: CJI for talking among each other and BI for showing politeness in conversations (Kushartanti 2009), reading aloud or praying. Children are immersed in these

3 Due to traffic congestions on weekdays, it is common that many of working people who live in Jabodetabek (= Jakarta Bogor Depok Tangerang Bekasi), the urban area surrounding Jakarta start their working days very early (around $6 \mathrm{am}$ ) and arrive at home very late (around $9 \mathrm{pm}$ ). This phenomenon has an impact on children's upbringing and the relationship between the family members (Kushartanti 2014b).

4 Note that at schools in Jakarta, Betawi language and culture is also taught. Betawi Malay and other regional languages have a special position in Indonesia. In the Addendum of Article 36 of the 1945 Constitution, it is said that regional languages should also be developed and maintained. The regional language planning is also regulated in Law no. 22 (1999) and Government Regulation no. 25 (2000) (Soedirja 2000). 
situations and get familiar with the use of the different language varieties. In other words: at a very early age Jakarta children are confronted with the need to use both CJI and BI appropriately.

In playgroup and kindergarten, children are not taught BI (nor a regional language) formally, but teachers introduce this variety in greetings, prayers, or story telling in the classroom. The use of BI is also preferred in the classroom. As parents do, teachers instruct the children to use some expressions in BI, see (1). Therefore, they can use (1) and (2) below in different situations: while (1) is conveyed before classmates in front of the classroom, (2) is used in a less formal situation (Kushartanti 2009; translation, phonetic transcription, and glossing are added by us). ${ }^{5}$

$\begin{array}{llllll}\text { (1) Teman-teman, } & \text { dengar-kan } & \text { ya } & \text { saya } & \text { mau } & \text { ber-cerita. } \\ \text { təman-təman, } & \text { dəyar-kan } & \text { ja, } & \text { saja } & \text { mau } & \text { bər cərita } \\ \text { friend } \sim \mathrm{PL} & \text { hear-CAUS } & \text { yes } & 1 \mathrm{sg} & \text { want } & \text { ACT.INTR-story }\end{array}$

'Friends, please listen to me, I want to tell you a story.'

(2) Hei, denger-in aku dong!

hei, dəђər-in aku dən

EXCL hear-CAUS 1SG FOC

'Hey, listen to me!'

Both examples show that children use different varieties in different situations: different lexical choices, saya 'I' (formal) and aku 'I' (informal), and different morphology, dengarkan (formal) and dengerin (informal), showing how children distinguish the BI suffix -kan from CJI -in.

In role-playing, children (aged 3-4 years old) also use "correct" BI, as illustrated in (3) (Kushartanti 2014a: 109):

(3) Some boys were playing "police and thief". CHI1 played a head commissioner, CHI2 played an officer, the others played the thieves.

$\begin{array}{llll}\text { CHI 1: } & \text { Cepat kau-tangkap pen-curi itu! } \\ \text { cəpat kaw-tankap } & \text { pən-curi itu } \\ & \text { quick 2sG-catch } & \text { Noun-steal that } \\ \text { 'Catch the thief, hurry!' } & & \end{array}$

CHI 2: Baik, Pak

baik pa?

good sir

'Yes, sir.'

$5 \mathrm{SG}=$ Singular, $\mathrm{PL}=$ Plural, $\mathrm{CAUS}=$ Causative, $\mathrm{ACT} . \mathrm{INTR}=$ Active Intransitive, $\mathrm{EXCL}=$ Exclamation, $\mathrm{FOC}=$ Focus . 
This example illustrates that children use BI lexical items: CHI1 uses cepat [cəpat] (BI) instead of cepet [cəpət] (CJI), kautangkap [kawtankap] (BI) instead of tangkep [tankəp] (CJI); CHI2 uses baik [baik] (BI) instead of baek [baek] (CJI). ${ }^{6}$

All these examples indicate that children, at a very young age, show sociolinguistic awareness about the appropriate use of language varieties in different situations.

\section{RESEARCH METHODS}

In this study we looked at language production of young children. The data were obtained from interviews in which the situation was conditioned as formal or informal. The interviews were conducted at schools in two periods with a six-month interval. To have an overall picture of the children in our study, we also observed the children outside the experimental setup, and we distributed parental questionnaires.

\subsection{THE CHILDREN}

Children in this study were selected from three private playgroups and kindergartens located in South Jakarta, Depok, and Tangerang. They were 3;0 to 4;5 when the first interviews were conducted. All of them come from middle-class families, and are second generation acquirers of Indonesian as a first language.

63 (sixty-three) children, consisting of 31 boys and 32 girls, participated in this study. These children were stratified into three cohorts. To the first cohort belong children who were born in the second semester of 2006 (2006_2); to the second cohort those born in the first semester of 2006 (2006_1); and to the third children born in the second semester of 2005 (2005_2). Therefore, in the first interviews, the first cohort children are 3;0-3;5 old; the second 3;6-3;11; and the third 4;0-4;5. Cohort 1 consists of 6 boys and 7 girls; Cohort 2 of 12 boys and 9 girls; and Cohort 3 of 13 boys and 16 girls. All the children were very cooperative and talkative enough to be involved in interactions such as turn taking and interviews.

From the parental questionnaires we learned that the parents used BI in interaction with their children, in many conditions and situations. Through our personal observations we knew that these children already used BI for prayers or role-playing. In many conditions - such as interacting with friends, helpers, caregivers (before and after school) as well as teachers - children were still more exposed to CJI, as illustrated in the Table 1 (Kushartanti 2014a: 110). 


\begin{tabular}{|c|c|c|c|c|c|}
\hline \multirow[t]{2}{*}{ Addressee } & \multirow[t]{2}{*}{ Activity } & \multirow[t]{2}{*}{ Setting(s) } & \multicolumn{3}{|c|}{ Language choice at school } \\
\hline & & & Catholic & Islamic & Public \\
\hline \multirow{8}{*}{ Teacher } & \multirow{2}{*}{ teaching } & \multirow{2}{*}{ classroom } & PG:BI/CJI & PG: BI/CJI & PG:BI/CJI \\
\hline & & & KG:BI & KG:BI & KG:BI/CJI \\
\hline & \multirow[b]{2}{*}{ playing } & \multirow{2}{*}{$\begin{array}{l}\text { classroom/ } \\
\text { playing } \\
\text { room/ } \\
\text { playground }\end{array}$} & \multirow[b]{2}{*}{ CJI } & PG: BI/CJI & \multirow[b]{2}{*}{ - CJI } \\
\hline & & & & $\begin{array}{l}\text { KG: mainly } \\
\text { BI }\end{array}$ & \\
\hline & \multirow[b]{2}{*}{ mealtime } & \multirow[b]{2}{*}{ classroom } & \multirow[b]{2}{*}{ CJI } & PG: BI/CJI & \multirow[b]{2}{*}{ CJI } \\
\hline & & & & $\begin{array}{l}\text { KG: mainly } \\
\text { BI }\end{array}$ & \\
\hline & warning & $\begin{array}{l}\text { indoor/ } \\
\text { outdoor }\end{array}$ & $\mathrm{BI}$ & $\mathrm{BI}$ & $\mathrm{BI}$ \\
\hline & praying & classroom & $\begin{array}{l}\text { BI/FL } \\
\text { (Eng.) }\end{array}$ & BI/FL (Ar.) & $\begin{array}{l}\text { BI/FL } \\
\text { (Ar./ } \\
\text { Eng.) }\end{array}$ \\
\hline \multirow{2}{*}{ Helper } & $\begin{array}{l}\text { changing } \\
\text { clothes }\end{array}$ & classroom & CJI & CJI & CJI \\
\hline & $\begin{array}{l}\text { accompany- } \\
\text { ing to toilet }\end{array}$ & toilet & CJI & CJI & CJI \\
\hline \multirow{4}{*}{ Friend } & studying & classroom & CJI & CJI & CJI \\
\hline & playing & $\begin{array}{l}\text { classroom/ } \\
\text { playing } \\
\text { room/ } \\
\text { playground }\end{array}$ & CJI & CJI & CJI \\
\hline & role-playing & $\begin{array}{l}\text { playing } \\
\text { room/ } \\
\text { playground }\end{array}$ & BI & $\mathrm{BI}$ & $\mathrm{BI}$ \\
\hline & chatting & $\begin{array}{l}\text { classroom/ } \\
\text { playing } \\
\text { room }\end{array}$ & CJI & CJI & CJI \\
\hline Caregiver & $\begin{array}{l}\text { before/after } \\
\text { school }\end{array}$ & outdoor & CJI & CJI & CJI \\
\hline
\end{tabular}

$(\mathrm{PG}=$ playgroup, $\mathrm{KG}=$ kindergarten, $\mathrm{BI}=$ Bahasa Indonesia, $\mathrm{CJI}=$ Colloquial Jakarta Indonesian, FL=foreign language, Eng.=English, Ar.=Arabic)

Table 1. Children's language choice patterns, split up by addressee, activity, setting and school.

\subsection{THE INSTRUMENTS AND RESEARCH DESIGN}

To elicit children's production from our interviews, we used pictures arranged as scenarios. Each scenario consisted of a series of A4-size water-coloured and laminated pictures. The topic of each scenario was familiar to both boys and girls. All of them are "neutral" topics, in the sense that both BI and CJI could be used in discussion. 
Our study was designed as a longitudinal study with two periods of data collection and four scenarios: Scenario A, a story about some activities in a traditional market; Scenario B, a story about a birthday party and some activities afterward; Scenario C, a story about having a holiday in a beach resort; and Scenario D, a story on having a holiday in a mountainous region. At each time point, we used these scenarios in both formal and informal situations.

In each picture of the scenario the utterances to be pronounced by the experimenter were tagged. In Scenarios A and B, there were 9 elicitation items, in Scenarios C and D 8 items. Besides the main questions, there were several filler questions exploring each picture, particularly on children's experiences related to the pictures.

The main targeted answers in this study were verbs aimed at eliciting the morphological variables of our study in BI and CJI. Children were asked to describe the actions (pointed to by the interviewers), which are normally expressed by verbs containing the target variables, namely the BI prefixes $m e N-$ and ber-, and their CJI counterparts, namely the nasal forms $(\mid m-1,1 n-/$, $/ n g-/, / n y-1), n g e-$, and the zero prefix $\varnothing$. We designed two different versions of our questions, a formal BI one and an informal CJI one. Both versions are given in the Table 2.

\begin{tabular}{|c|c|c|c|c|c|}
\hline \multicolumn{3}{|c|}{ 'What is she/he doing?' } & \multicolumn{3}{|c|}{ / 'What are they doing?' } \\
\hline \multicolumn{3}{|c|}{$\mathrm{BI}$} & \multicolumn{3}{|c|}{ CJI } \\
\hline Dia & sedang & apa? & Dia & lagi & ng-apa-in? \\
\hline 3SG & PROG & what & $3 \mathrm{SG}$ & PROG & ACT-what-ACT \\
\hline \multicolumn{3}{|c|}{ 'what is s/he doing?' } & \multicolumn{3}{|c|}{ 'what is s/he doing?' } \\
\hline Mereka & sedang & apa? & Mereka & lagi & $n g$-apa-in \\
\hline 3PL & PROG & what & 3PL & PROG & ACT-what-ACT \\
\hline \multicolumn{3}{|c|}{ 'what are they doing?' } & \multicolumn{3}{|c|}{ 'what are they doing?' } \\
\hline
\end{tabular}

Table 2. Questions to elicit the morphological variables in BI and CJI (Kushartanti 2014a: 78). ${ }^{7}$

We separated each cohort into two sub-cohorts; each of them having a different setting for the interview while both interviewers used the same scenario at the same time point of data collection. In the first session of the first period of data collection, half of each cohort had Scenario A in the formal session which is in BI, while the other half, using the same scenario, was interviewed in the informal situation (in CJI). In the second session, they switched situations, and Scenario B was used. In the second period of data collection, the tasks and the orders of scheduled interviews were the same, but now Scenarios $C$ and D were used. The whole scheme is presented in Table 3. 


\begin{tabular}{|c|c|c|c|c|c|c|c|}
\hline & & \multicolumn{2}{|c|}{ Cohort 1} & \multicolumn{2}{|c|}{ Cohort 2} & \multicolumn{2}{|c|}{ Cohort 3} \\
\hline & & BI & CJI & BI & CJI & BI & CJI \\
\hline \multirow[t]{2}{*}{$\begin{array}{l}\text { 1st } \\
\text { Period }\end{array}$} & $\begin{array}{l}\text { 1st } \\
\text { session } \\
\text { Scenario } \\
\text { A }\end{array}$ & $\begin{array}{l}\text { sub- } \\
\text { cohort } \\
\text { (1) }\end{array}$ & $\begin{array}{l}\text { sub- } \\
\text { cohort } \\
(2)\end{array}$ & $\begin{array}{l}\text { sub- } \\
\text { cohort } \\
\text { (1) }\end{array}$ & $\begin{array}{l}\text { sub- } \\
\text { cohort } \\
\text { (2) }\end{array}$ & $\begin{array}{l}\text { sub- } \\
\text { cohort } \\
\text { (1) }\end{array}$ & $\begin{array}{l}\text { sub- } \\
\text { cohort } \\
(2)\end{array}$ \\
\hline & $\begin{array}{l}\text { 2nd } \\
\text { session } \\
\text { Scenario } \\
\text { B }\end{array}$ & $\begin{array}{l}\text { sub- } \\
\text { cohort } \\
(2)\end{array}$ & $\begin{array}{l}\text { sub- } \\
\text { cohort } \\
(1)\end{array}$ & $\begin{array}{l}\text { sub- } \\
\text { cohort } \\
\text { (2) }\end{array}$ & $\begin{array}{l}\text { sub- } \\
\text { cohort } \\
\text { (1) }\end{array}$ & $\begin{array}{l}\text { sub- } \\
\text { cohort } \\
\text { (2) }\end{array}$ & $\begin{array}{l}\text { sub- } \\
\text { cohort } \\
\text { (1) }\end{array}$ \\
\hline \multirow{2}{*}{$\begin{array}{l}\text { 2nd } \\
\text { Period }\end{array}$} & $\begin{array}{l}\text { 1st } \\
\text { session } \\
\text { Scenario } \\
\text { C }\end{array}$ & $\begin{array}{l}\text { sub- } \\
\text { cohort } \\
\text { (1) }\end{array}$ & $\begin{array}{l}\text { sub- } \\
\text { cohort } \\
\text { (2) }\end{array}$ & $\begin{array}{l}\text { sub- } \\
\text { cohort } \\
\text { (1) }\end{array}$ & $\begin{array}{l}\text { sub- } \\
\text { cohort } \\
\text { (2) }\end{array}$ & $\begin{array}{l}\text { sub- } \\
\text { cohort } \\
\text { (1) }\end{array}$ & $\begin{array}{l}\text { sub- } \\
\text { cohort } \\
\text { (2) }\end{array}$ \\
\hline & $\begin{array}{l}\text { 2nd } \\
\text { session } \\
\text { Scenario } \\
\text { D }\end{array}$ & $\begin{array}{l}\text { sub- } \\
\text { cohort } \\
(2)\end{array}$ & $\begin{array}{l}\text { sub- } \\
\text { cohort } \\
(1)\end{array}$ & $\begin{array}{l}\text { sub- } \\
\text { cohort } \\
(2)\end{array}$ & $\begin{array}{l}\text { sub- } \\
\text { cohort } \\
\text { (1) }\end{array}$ & $\begin{array}{l}\text { sub- } \\
\text { cohort } \\
(2)\end{array}$ & $\begin{array}{l}\text { sub- } \\
\text { cohort } \\
\text { (1) }\end{array}$ \\
\hline
\end{tabular}

Table 3. Data collection scheme (source: Kushartanti 2014a: 85).

\subsection{THE INTERVIEWERS AND SETTINGS}

As the main goal of this study is to investigate whether children are able to style-shift in two different situations, we conducted two different interviews, one in BI, and one in CJI. The formal and informal interviews were conducted in different settings, in accordance with the interviewers' speech style respectively. The interview sessions were recorded with a camera and a voice recorder.

Two female interviewers conducted the interviews, each using the variety that represented the style. One female in her 40's consistently used BI during her presence at school, especially before the children, and even when playing with the children. She is the interviewer in the formal-conditioned interview (henceforth: ForIn). The other interviewer (henceforth: InfIn), who was in her 20's, consistently used CJI at school and in the classroom conducting the informal-conditioned interviews. Both interviewers were similarly dressed, but they behaved differently towards the children: the older interviewer posed as a mother to the children, the younger one posed as a big sister. In Table 4, we summarize the differences between both interviewers' characteristics and the settings split up by speech style. 


\begin{tabular}{l|l|l|l}
\hline \multicolumn{2}{l|}{} & Formal & Informal \\
\hline \multirow{4}{*}{} & Name & ForIn & InfIn \\
\cline { 2 - 4 } & Variety & BI & CJI \\
\cline { 2 - 4 } & Age & 40 & 22 \\
\cline { 2 - 4 } $\begin{array}{l}\text { Interviewer's } \\
\text { characteristics }\end{array}$ & $\begin{array}{l}\text { Pose to the } \\
\text { children }\end{array}$ & mother-like & sister-like \\
\cline { 2 - 4 } & Appearance & semi-formal dress & semi-formal dress \\
\cline { 2 - 4 } & Position & $\begin{array}{l}\text { sitting on chairs } \\
\text { at a table }\end{array}$ & $\begin{array}{l}\text { sitting on the floor } \\
\text { or in a playhouse }\end{array}$ \\
\cline { 2 - 4 } & $\begin{array}{l}\text { Physical } \\
\text { distance }\end{array}$ & distanced & close \\
\hline \multirow{4}{*}{$\begin{array}{l}\text { Settings } \\
\text { Location }\end{array}$} & $\begin{array}{l}\text { classroom/lab/prayer } \\
\text { room/library }\end{array}$ & $\begin{array}{l}\text { playground/play } \\
\text { room/corridors/ } \\
\text { playhouse }\end{array}$ \\
\cline { 2 - 4 } & $\begin{array}{l}\text { Familiar } \\
\text { person } \\
\text { around the } \\
\text { child (only } \\
\text { in the first } \\
\text { interview }\end{array}$ & teacher & $\begin{array}{l}\text { mother/grandmother/ } \\
\text { nanny/servant }\end{array}$ \\
\hline
\end{tabular}

Table 4. Interviewers' characteristics and settings, split up by speech style (Kushartanti 2014a: 89).

\section{CHILDREN'S USE OF BI AND CJI}

For this first analysis of the children's use of BI and CJI all utterances by the children in the interviews were used. For the analysis presented in Section 4, we will focus exclusively on the spontaneously produced verbal forms, elicited by the techniques described in Section 2.2. Four types of utterances were distinguished: Bahasa Indonesia utterances (BIu), Colloquial Jakarta utterances $(\mathrm{CJIu})$, unmarked utterances (UNMu), and mixed utterances (MIXu).

Utterances are coded as (BIu) if the utterance (a complete or truncated sentence) has the characteristics of $\mathrm{BI}$ on all linguistic levels. The characteristics of BI are described in Tata Bahasa Baku Bahasa Indonesia (Alwi et al. 2000).

Utterances are coded as (CJIu) if the utterance (a complete or truncated sentence) has the characteristics of CJI on all linguistic levels. In the Kamus Besar Bahasa Indonesia (2008), or the official monolingual Indonesian dictionary, CJI lemmas are marked as cak. (abbreviated form of percakapan 'conversation' or 'colloquial'). Some of them are not found in the dictionary, but used in daily and casual conversation (see also Sneddon 2006).

Many nouns, adjectives, and infinitive verbs, such as rumah 'house', nakal 'naughty', and pergi ' go' are unmarked, as they are exactly the same in BI and CJI. Back-channel utterances such as hmm or ya 'yes' were also categorized as unmarked utterances (UNMu). 
The mixed utterances (MIXu) have a combination of BI- and CJI-elements. At the lexical level, a mixed word is a combination of a CJI stem and a BI affix, or vice versa. In larger constructions, mixed utterances may be a combination such as lagi membersihkan '(s.o.) is cleaning', which is a combination of CJI (lagi) and BI (membersihkan) (Kushartanti 2014a: 97-98).

The distribution of the utterances is presented in Table 5. The table shows for each variable the use of the utterances in both periods and both situations, presenting the mean values (M) and the standard deviation (SD). The variables were analysed with Mixed Models Analyses (REML method), ${ }^{8}$ with child and school (nested under school) as random factors, and period, situation, age cohort, and gender as fixed factors. The full analyses can be found in Kushartanti (2014a: 121-126). An overview of the significant effects is presented in Table 6.

\begin{tabular}{lccccr}
\hline \multirow{2}{*}{ N=252 } & Period & \multicolumn{2}{c}{ Formal } & \multicolumn{3}{c}{ Informal } \\
\cline { 2 - 6 } & 1 & $\mathrm{M}$ & $\mathrm{SD}$ & $\mathrm{M}$ & $\mathrm{SD}$ \\
\cline { 3 - 6 }$(\mathrm{CJIu})$ & 2 & 41.9 & 14.9 & 55.2 & 10.4 \\
& 1 & 43.2 & 16.4 & 54.2 & 9.9 \\
\hline \multirow{2}{*}{$(\mathrm{BIu})$} & 2 & 12.8 & 11.2 & 4.5 & 3.6 \\
& 1 & 21.3 & 14.2 & 10.8 & 8.2 \\
\hline \multirow{2}{*}{$(\mathrm{MIXu})$} & 2 & 8.2 & 7.4 & 2.1 & 2.7 \\
& 1 & 7.5 & 7.2 & 4.1 & 3.8 \\
\hline \multirow{2}{*}{$(\mathrm{UNMu})$} & 2 & 37.1 & 11.6 & 38.2 & 11.3 \\
& 2 & 28.0 & 9.7 & 31.0 & 9.0 \\
\hline
\end{tabular}

Table 5. Distribution of the utterances, split up by period and situation.

Table 5 shows that children most frequently used (CJIu) in the interview, reflecting their dominance in CJI. There is a significant effect of situation: the children's use of (CJIu) was higher in the informal $(M=54.7, S D=10.1)$ than in the formal $(M=42.5, S D=15.6)$ situation. There are no significant effects of period or cohort, nor any significant interactions between these factors and situation. There is a significant interaction between situation and gender: in the informal situation girls $(M=56.7, S D=8.9)$ used slightly more (CJIu) than boys $(M=52.6, S D=10.9)$, while in the formal situation boys $(M=43.1, S D=16.4)$ used slightly more (CJIu) than girls $(\mathrm{M}=42.0, \mathrm{SD}=14.9)$. It suggests that girls might be a bit more responsive to the situation than boys, using more CJI in the informal situation and less in the formal situation. However, we should be careful with this interpretation as differences and effect sizes are small. Furthermore, there is a significant random effect of child, indicating that individual differences are high. 


\begin{tabular}{lll}
\hline & Random & Fixed \\
\hline$(\mathrm{CJIu})$ & Child & $\begin{array}{l}\text { Situation } \\
\text { Situation } \times \text { Gender }\end{array}$ \\
\hline$(\mathrm{BIu})$ & Child & $\begin{array}{l}\text { Situation } \\
\text { Period }\end{array}$ \\
\hline \multirow{2}{*}{$(\mathrm{MIXu})$} & Child & $\begin{array}{l}\text { Situation } \\
\text { Situation } \times \text { Period }\end{array}$ \\
\hline \multirow{2}{*}{$(\mathrm{UNMu})$} & Child & $\begin{array}{l}\text { Period } \\
\text { Cohort }\end{array}$ \\
\hline
\end{tabular}

Table 6. Overview of significant factors, mixed models analyses, based on Kushartanti (2014a: 121-126).

The children also used (BIu), but with a much lower frequency than (CJIu). There are only significant effects of situation and period. (BIu) was used more frequently in the formal $(\mathrm{M}=17.1, \mathrm{SD}=13.4)$ than in the informal situation $(\mathrm{M}=7.7, \mathrm{SD}=7.0)$, showing that overall the children accommodated to the formal situation by increasing their use of BI. In general, the children almost doubled their use of (BIu) in the 2nd period ( $M=16.1, S D=12.7)$ in comparison with the 1st period $(M=8.6, S D=9.3)$. However, it should be noted that the children started with a very low use of $(\mathrm{BIu})$ and that there is no interaction between period and situation, indicating that they increased their use of BI in both situations. So, the preschoolers apparently learned to use BI over time, were sensitive to style, but their stylistic competence (that is, their ability to switch between the two varieties in line with the situation) did not develop in the time period we studied (six months). It should also be noted that there are large individual differences (random effect of child) and that there are no differences between the three cohorts.

Mixed utterances (MIXu), an example is given in (4), have a low frequency (see Table 5), and the results of the statistical analysis should be handled with care. There are significant effects of situation and of the interaction between situation and period. The higher use of (MIXu) in the formal $(\mathrm{M}=7.8)$ than in the formal situation $(M=3.1)$, might be an indication of the children's ability to assess the situation and of their attempt to converge their speech to the interviewer's speech style using more BI elements, not always resulting in complete BI utterances. The interaction (see Table 5) is due to a small increase in the use of (MIXu) in the informal situation, which is in line with the observed increase of $(\mathrm{BIu})$ in the informal situation. 
(4) a. sedang ny-(s)apu [sədan napu]

PROG ACT.TR-Sweep

(BI) (CJI)

' $\mathrm{X}$ is sweeping.'

b. meny-(c)opot-in [mənəpotin]

ACT.TR-pull out-TR

(BI) (CJI) (CJI)

'to pull out'

Unmarked utterances (UNMu) are frequently used in both situations, and there are significant effects of period, cohort and the random factor child. The latter one indicates that there are large individual differences. Many of the unmarked utterances are instances of back-channel behavior, functioning as a "bridge". They are an indication that the children paid attention to the interlocutor's speech, were responsive to their interlocutor and that they had basic turn-taking capacities in their interaction with adults. That the use of (UNMu) decreased over time (1st period: $M=37.6, S D=11.4$; 2nd period: $M=29.5, S D=9.5)$ is not surprising and is a result of the fact that children answered more with a sentence, instead of unmarked back-channel utterances as hmm, he-eh 'yes' or ya 'yes'. The cohort effect is small, only the oldest generation used a bit less (UNMu) than the middle generation.

The findings in this section confirm that CJI is the children's dominant variety. CJI is used most frequently in both formal and informal situations. At the same time, we notice that children are sensitive to style: the use of CJI is higher in the informal than in the formal situation, the use of BI (not always resulting in full BI utterances, but mixed ones) is higher in the formal than in the informal situation, and the use of BI increases over time. However, there are large individual differences, and some children even use BI in the informal situation (see also Section 4). Finally, all children understand BI, as shown by their turn taking capacities and their participation in the interviews.

It should be noted that the utterances analyzed in Section 3 are part of the whole interview, including children's repetitions of the interviewer's speech. In Section 4 we will assess the children's ability to spontaneously produce $\mathrm{BI}$ and CJI.

\section{THE USE OF BI VERBS}

We now focus exclusively on the children's answers to the elicitation questions, which elicited verbs containing one of our target variables. The distribution of the BI and CJI verbs is presented in Figure 1, showing the mean scores of (BIv) and (CJIv) split up by situation and period. 


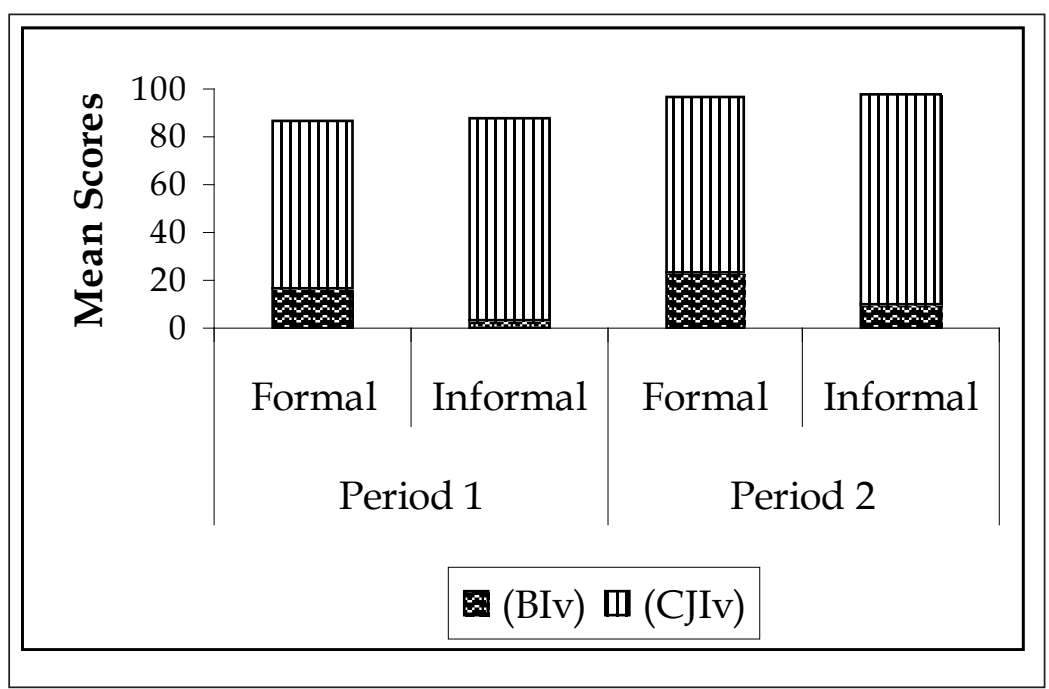

Figure 1. Distribution of (BIv) and (CJIv) in both periods and situations.

\begin{tabular}{|c|c|c|c|c|}
\hline FIXED FACTORS & df1 & df2 & $\mathrm{F}$ & $\mathrm{p}$ \\
\hline Intercept & 1 & 1.740 & 29.891 & .043 \\
\hline Cohort & 2 & 55.819 & .417 & .661 \\
\hline Gender & 1 & 56.893 & .217 & .643 \\
\hline Situation & 1 & 171 & 33.575 & .000 \\
\hline Period & 1 & 171 & 10.208 & .002 \\
\hline Cohort * Gender & 2 & 56.773 & .718 & .492 \\
\hline Cohort * Situation & 2 & 171 & .442 & .643 \\
\hline Cohort * Period & 2 & 171 & .103 & .902 \\
\hline Gender * Situation & 1 & 171 & .062 & .804 \\
\hline Gender * Period & 1 & 171 & .290 & .591 \\
\hline Situation * Period & 1 & 171 & .280 & .597 \\
\hline Cohort * Gender * Situation & 2 & 171 & .855 & .427 \\
\hline Cohort * Gender * Period & 2 & 171 & 1.016 & .364 \\
\hline Cohort * Situation * Period & 2 & 171 & .128 & .880 \\
\hline Gender * Situation * Period & 1 & 171 & 1.095 & .297 \\
\hline Cohort * Gender * Situation * Period & 2 & 171 & 2.499 & .085 \\
\hline RANDOM FACTORS & & Estimates & SE & $\mathrm{p}$ \\
\hline School & & 6.45 & 15.49 & .677 \\
\hline Child & & 81.84 & 28.80 & .004 \\
\hline
\end{tabular}

$(\mathrm{df}=$ degree of freedom, $\mathrm{p}=$ significance level, $\mathrm{SE}=$ Standard Error, AIC $=$ Akaike's Information Criterion)

Table 7. (BIv): Results of mixed models analysis. 
Children used (CJIv) more frequently than (BIv) in both situations. A paired sample $\mathrm{t}$-test indicates that there is a significant difference between the mean scores of (BIv) and (CJIv), $t(251)=-27.163, p<.001 .{ }^{9}$ We will focus on the children's use of (BIv), as BI is the new variety they are acquiring in the preschool setting, and present the results of a Mixed Models Analyses (REML method) with child and school (nested under school) as random factors, and period, situation, age cohort, and gender as fixed factors. The results are presented in Table 7.

There is a significant random effect of child, and a significant fixed effect of situation, and period. Children use (BIv) more frequently in the formal situation $(M=20.1, S D=23.6)$ than in the informal one $(M=6.5, S D=11.3)$, showing that in general the children were already aware of stylistic differences and able to produce stylistically appropriate and variety specific verbal forms. Children also used (BIv) more frequently in the second ( $M=16.6, S D=20.7)$ than in the first period $(M=10.1, S D=18.2)$. There is no significant interaction between situation and period, which indicates that the children increased the use of (BIv) in both situations.

The significant random effect of child indicates that there are large individual differences and that not all the children share the same pattern in their use of (BIv). In the first formal interview, we observed already that some children had high scores of (BIv), while others had lower scores, and some even did not use BI verbs at all. In comparison with the first period, we observed that in the second period some children kept their (BIv) score, while others showed an increase and some even a decrease, despite the overall increasing tendency. In order to get more insight in the individual development in the use of (BIv), the children's use of (BIv) was classified in terms of stability over time (6 months period). Unstable speakers are defined as those having at least a difference of two tokens in the compared elicitation tasks (which targeted at having 8 or 9 observations of the variables, see Section 2.). This results in five categories: strong increase $(+50 \leq x \leq+100)$, moderate increase $(+15 \leq x<+50)$, stable $(-15<x<+15)$, moderate decrease $(-15 \leq x<-50)$, and strong decrease $(-50 \leq x \leq-100)$. The distribution over the categories, split up by situation is presented in Table 8 .

In Figures 2a and 2b, the individual patterns of the development of (BIv) (connecting the index score of the 1st and 2nd period) in both formal and informal situations are presented.

\footnotetext{
$9 \quad t=$ ratio of estimated parameter and its standard error; $\mathrm{p}=$ significance level: the less the value of the result, the more significant.
} 


\begin{tabular}{l|c|c|c|c}
\hline \multirow{2}{*}{$\begin{array}{l}\text { Individual pattern } \\
\text { (difference period 2 - period 1) }\end{array}$} & \multicolumn{2}{|c|}{ Formal situation } & \multicolumn{2}{c}{ Informal situation } \\
\cline { 2 - 5 } & $\begin{array}{c}\text { Number } \\
\text { of children }\end{array}$ & $\%$ & $\begin{array}{c}\text { Number } \\
\text { of children }\end{array}$ & $\%$ \\
\hline $\begin{array}{l}\text { Strong increase } \\
+50 \leq x \leq+100\end{array}$ & 5 & 7.9 & 1 & 1.6 \\
\hline $\begin{array}{l}\text { Moderate increase } \\
+15 \leq x<+50\end{array}$ & 15 & 23.8 & 8 & 12.7 \\
\hline $\begin{array}{l}\text { Stable } \\
-15<x<+15\end{array}$ & 35 & 55.6 & 54 & 85.7 \\
\hline $\begin{array}{l}\text { Moderate decrease } \\
-15 \leq x<-50\end{array}$ & 5 & 7.9 & 0 & 0.0 \\
\hline $\begin{array}{l}\text { Strong decrease } \\
-50 \leq x \leq-100\end{array}$ & 3 & 4.8 & 0 & 0.0 \\
\hline
\end{tabular}

Table 8. Changes in the individual scores of (BIv) between the 1st and 2nd period $(n=63)$.
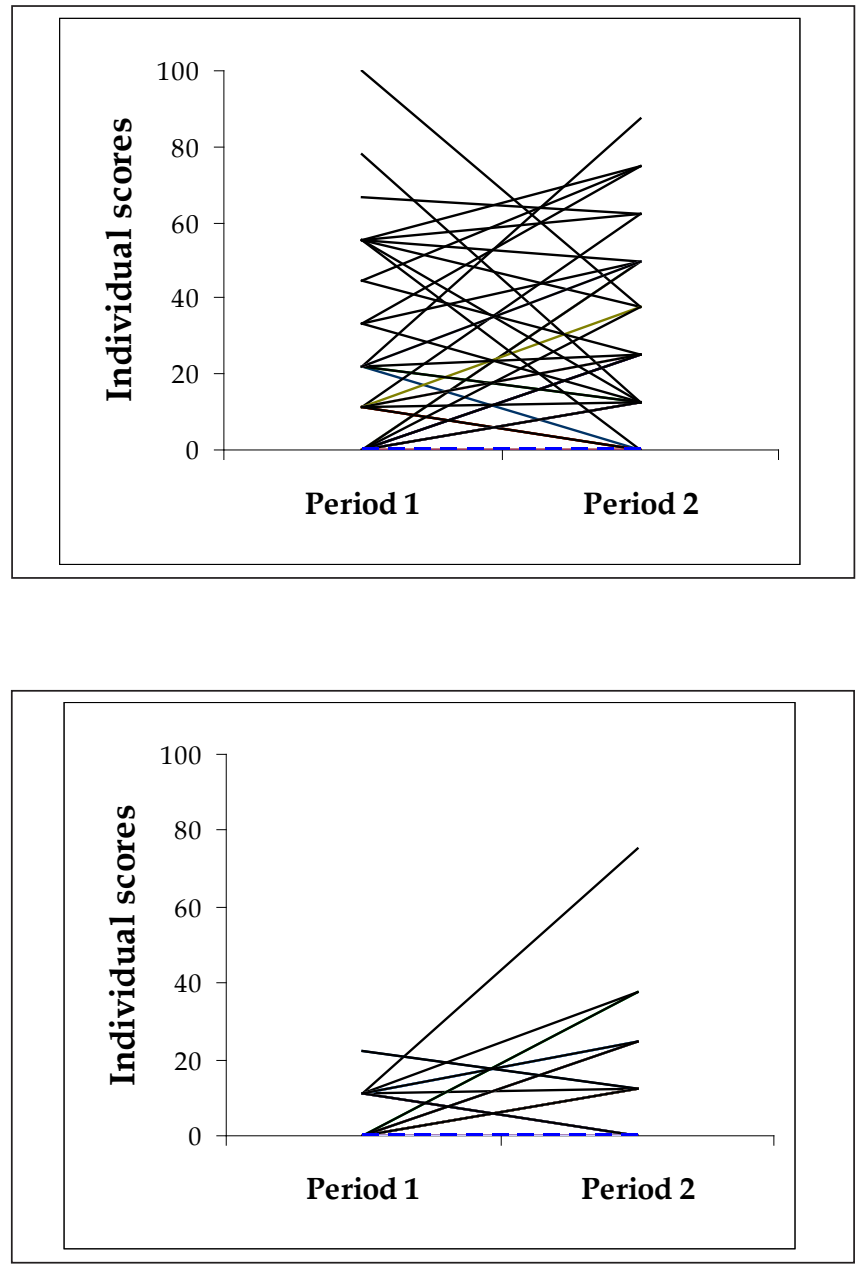

Figure 2a. Changes of (BIv) in the formal situation (Individual scores).
Figure 2b. Changes of (BIv) in the informal situation (Individual scores). 
Figure 2a shows various patterns of change in the formal situation. Many children had low scores in the first period of the formal conditioned interview; some of them continued to do so in the second period. More than half of the children ( 35 out of 63 ) remained stable, even though they had considerable margin to increase their use of (BIv). We also see that there are children who showed a moderate $(n=15)$ and strong increase $(n=5)$ in the use of $(B I v)$. Several children who had a low score in the first period, developed the use of (BIv) in the second one, indicating that there was a learning process during the interval period. Five children had a moderate decrease in the use of (BIv). Note that three children who started with high scores of (BIv) drastically decreased its use six months later.

Figure $2 \mathrm{~b}$ shows that for all children the score of (BIv) in the informal situation was very low in the first period. In majority (54 out of 63), children kept this low score. Some even never used a BI verb form in the informal situation. The findings might suggest that these children were able to assess the situation as informal, and therefore exclusively stick to CJI verb forms. However, there are some exceptions as nine children increased the score of (BIv) over time in the formal situation, one of them even strongly.

In the following section we will try to provide some explanations for the large individual differences and some of the conflicting patterns.

\section{SOME EXPLANATIONS FOR THE LARGE INDIVIDUAL DIFFERENCES}

There is not a straightforward development of the use of BI in the formal situation and it is observed that there are large differences between the children in both the frequency and the development of the use of BI in formal and informal situations. We will try to provide explanations for the dominant use of CJI during the interviews, also in the formal situation, and for the conflicting developmental patterns observed in Section 4.

It should be repeated first that all children have at least listening competence in BI, as they were able to understand the formal interviewer and to engage in a conversation with her. In fact, all children were able to speak BI too. Three children who never used BI during the interviews were observed speaking it during other activities at school, such as role-playing. Second, almost all children are CJI dominant and speak it as their first language, to which BI is added, partly at home, but especially in the preschool setting of the private kindergartens they attend.

The differences between the children might be partly explained by factors outside our control, as we did not follow the children during the six month interval, nor at home, nor at school. Sometimes individual differences can be explained by the child's mood on the occasion of one of the interviews. The results of two girls illustrated how different moods may affect language use. One girl, who was in a very good mood and who was included in those who had score of $>50$ in BI use in the first interview, became very at ease in the formal situation in the second interview, resulting in a shift towards CJI. Another girl, who had one of the highest score of BI in the first period, was 
in a very bad mood during the second session and shifted to CJI.

But also methodological issues might play a role and the experimental setting and the interviewers might have affected the children's language use (Romaine 1984; Coupland 2011). The school setting might increase the use of $\mathrm{BI}$ in the informal situation, as the school is the main environment where they hear and learn to use BI. Labov (2001: 437) also suggested that "formal speech variants are associated by children with instruction and punishment, informal speech with intimacy and fun". This is also in line with the parents' claims in the parental questionnaires, that they use BI to give instructions and to show anger. Some of the children even indicated that they were not at ease when they participate in the first formal interview. We also used one formal interviewer (always speaking BI and middle-aged) and one informal interviewer (always speaking CJI and mid twenties) in both periods. The 2nd interview, also in the formal situation, might be considered less formal by some of the children, due to the fact that they were more familiar with the formal interviewer than during the first interview. Consequently, these children will be on the more informal side of their style continuum, and use less BI characteristics than they could/would do in another formal setting, with another formal interviewer. For these children it results in an underestimation of their BI productive skills in the 2 nd period. Next to that, the presence of audio and video recording equipment might elicit the use of $\mathrm{BI}$, also in the informal situation. So, it might be a partial explanation for the increased use of $\mathrm{BI}$ in the 2 nd period in the informal situation.

Finally, peers might also play a role in the choice between BI and CJI. Especially the children who were fluent users of BI in the formal situation in the first period and shifted to mainly CJI use in the second period, might be influenced by solidarity with their peers, who are almost all dominant CJI speakers. Similar adaptations to peer groups by children have been observed already by Labov (1964), Payne (1980), Chesterfield et al. (1983), Ervin-Tripp (1991), Gertner et al. (1994), and Justice et al. (2011).

Some small methodological problems and issues behind the control of the researchers (and that are part of real life) may have influenced the results of our study, but we do not think they threaten the main results and conclusion of this study.

\section{CONCLUSION}

This study, which is one of the first on the acquisition of variation and stylistic competence by young children, showed that Jakarta middle class children between three and five years old understand and actually started using BI in a formal situation. However, they are dominant in CJI, and their sociolinguistic competence to switch between CJI and BI, is not yet fully developed. CJI is their first language, and BI is the variety in which children learn formality, politeness, or warning - conditions where children are naturally less at ease. Yet, they know that it is used not merely for the aforementioned conditions, as they also use it in the role-playing - an activity which is really enjoyed by 
these children. They are exposed to BI at home, but it is used and learn more at playgroup and kindergarten, as the language of instruction at school.

We have shown that, in general, the children increase their use of BI, especially in formal situations, over a period of six months. Surprisingly, no differences between the three age cohorts showed up, which needs more research, which should also take into account some of the methodological drawback of our study.

The children maintain the use of CJI. Even though the use of BI is generally more favorable and favored by teachers in a school setting, the use of CJI is not "forbidden". As we conducted our study in such setting, we observed that these children, even at very young age, develop their knowledge of the function of both Indonesian varieties in this institution: while CJI functions as the means of informal communication and as the language of solidarity; BI functions as the language of religious affairs, education, and certainly, formality.

Apparently, knowledge on the function of BI is learned later, and these children are still struggling to master it. In other words: they are still learning to be competent Indonesian speakers, as a part of achieving their sociolinguistic competence.

\section{REFERENCES}

Alwi, H., et al. 2000. Tata Bahasa Baku Bahasa Indonesia. Edisi Ketiga. Jakarta: Balai Pustaka.

Arka, I.W. 2013. “Language management and minority language maintenance in (eastern) Indonesia; Strategic issue", Language Documentation and Conservation 7: 74-105.

Chesterfield, R., et al. 1983. "The influence of teachers and peer on second language acquisition in bilingual preschool program", TESOL Quarterly 17(3): 401-419.

Coupland, N. 2011. “The sociolinguistics of style”, in: R. Mesthrie (ed.), The Cambridge Handbook of Sociolinguistics, pp.138-156. Cambridge: Cambridge University Press.

Da Silva, Anna Marietta. 2013. “The English borrowings and the IndonesianEnglish code-switching in two collections of blog short stories", Kata Vol.15 No.1 (June): 9-18.

Ervin-Tripp, S. 1991. "Play in language development", in: B. Scales, M. Almy, A. Nicolopolou, and S.M. Ervin-Tripp (eds), Play and the social context of development in early care and education, pp. 84-98. New York: Columbia Teachers College.

Gertner, B. L., M. L. Rice, and P. A. Hadley. 1994. “Influence of communicative competence on peer influence in preschool classroom", Journal of Speech and Hearing Research 37: 913-923.

Grijns, C.D. 1981. "Jakartan speech and Takdir Alisjahbana's plea for the simple Indonesian word-form", in: N. Phillips and K. Anwar (eds), 
Papers on Indonesian Language and Literature, pp. 1-34. London: Indonesian Etymological Project.

Gunarwan, A. 1984. A sociolinguistic study of grammatical variation in Indonesian. $\mathrm{PhD}$ thesis, Georgetown University, Washington DC.

Justice, L.M., et al. 2011. "Peer effect in preschool classroom; Is children's language growth associated with their classmates' skills?", Child Development 82(6): 1768-1777.

Kamus Besar Bahasa Indonesia. 2008. Kamus Besar Bahasa Indonesia. Compiled and edited by Tim Redaksi KBBI-Pusat Bahasa. Jakarta: Gramedia Pustaka Utama dan Pusat Bahasa Departemen Pendidikan Nasional RI.

Kridalaksana, H. 2010. Masa-masa awal Bahasa Indonesia. Depok: Laboratorium Leksikologi dan Leksikografi, Fakultas Ilmu Pengetahuan Budaya Universitas Indonesia.

Kushartanti, B. 2009. "Strategi kesantunan bahasa pada anak-anak usia prasekolah: mengungkapkan keinginan", Linguistik Indonesia 27 (2): 257-270.

Kushartanti, B. 2014a. The acquisition of stylistic variation by Jakarta Indonesian children. Utrecht: LOT.

Kushartanti, B. 2014b. "Kesantunan untuk anak-anak; Apa yang baik menurut orang dewasa di Jabodetabek?", in: B. Kushartanti, M.S. Pattinasarany, Y.P. Anabel, N.S. Wrihatni, and R.N. Pramanik (eds), Prosiding Seminar Internasional Semiotik, Pragmatik, dan Kebudayaan; Peran Semiotik dan Pragmatik dalam memaknai kebudayaan global dan lokal, pp. 180-197. Depok: Departemen Linguistik, Fakultas Ilmu Pengetahuan Budaya Universitas Indonesia.

Kushartanti, B., et al. 2010. "Parents' language use and language attitude towards languages in Jakarta as part of language acquisition process". [Paper, Seminar Hasil Penelitian Kolaboratif Indonesia Goes International (IGI), Universitas Indonesia, Depok, 15 December.]

Labov, W. 1964. "Stages in the acquisition of Standard English", in: R. Shuy, A. Davis, and R. Hogan (eds), Social dialects and language learning; Proceeding of the Bloomington, Indiana Conference, pp. 77-104. Champaign, IL: National Council of Teachers of English.

Labov,W. 2001. Principles of linguistic change. Vol. 2: Social factors. Oxford and Massachusetts: Blackwell.

Lauder, A. 2008. "The status and function of English in Indonesia; A review of key factors", Makara; Sosial Humaniora Vol.12 No.1 (July): 9-20.

Muhadjir. 2000. Bahasa Betawi; Sejarah dan perkembangannya. Jakarta: Yayasan Obor.

Nababan, P.W.J. 1992. Survei kedwibahasaan di Indonesia. Jakarta: Pusat Pembinaan dan Pengembangan Bahasa, Departemen Pendidikan dan Kebudayaan.

Oetomo, D. 1990. "The Bahasa Indonesia of the middle class", Prisma; The Indonesian Indicator 50 (September): 68-79.

Payne, A. 1980. "Factors controlling the acquisition of the Philadelphia dialect 
by out-of state children", in: W. Labov (ed.), Locating language in time and space, pp. 143-178. New York: Academic Press.

Purwo, B. K. 1997. "Ihwal bahasa baku tak baku; Bahasa yang baik dan tidak benar?", Atma nan Jaya 10 (3): 49-63.

Romaine, S. 1984. The language of children and adolescent; The acquistion of communicative competence. Oxford: Blackwell.

Schleppegrell, M. J. 2001. "Linguistic features of the language of schooling", Linguistics and Education 12 (4): 431-459.

Smith-Hefner, N. 2007. "Youth language, Gaul Sociability, and the new Indonesian middle-class", Journal of Linguistic Anthropology 17(2): 184-203. Sneddon, J. 2003. "Diglossia in Indonesian", Bijdragen tot de Taal-Land-en Volkenkude 159(4): 519-549.

Sneddon, J. 2004. "The sociolinguistic nature of Indonesian today", in: K.E. Sukamto (ed.), Menabur benih menuai kasih; Persembahan karya bahasa, sosial, dan budaya untuk Anton M. Moeliono pada ulang tahunnya yang ke-75, pp. 3351. Jakarta: Universitas Katolik Indonesia Atma Jaya dan Yayasan Obor. Sneddon, J. 2006. Colloquial Jakartan Indonesian. Canberra: Pacific Linguistics. Soedirja, Soerjadi. 2000. "Peranan Bahasa dan Sastra Daerah dalam Pelaksanaan Otonomi“. [Paper, Konferensi Bahasa Daerah, Jakarta, 6-8 November.]

Tilden, K.E.R. 1985. Sociolinguistic aspects of Jakarta dialect switching in Bahasa Indonesia in eight Indonesian novels. PhD thesis, University of Michigan.

Wouk, F. 1989. The impact of discourse on grammar; Verb morphology in spoken Jakarta Indonesian. PhD thesis, University of California, Los Angeles.

Wouk, F. 1999. "Dialect contact and koineization in Jakarta, Indonesia", Language Sciences 21: 61-86.

\section{ABOUT THE AUTHORS}

BERNADETTE KUSHARTANTI took her PhD at Utrecht University, The Netherlands with a study on the acquisition of stylistic variation by Jakarta Indonesian children (2014). Upon finishing her dissertation, she has continued working as a lecturer at the Graduate Program of Linguistics Department, Faculty of Humanities, Universitas Indonesia. She works mainly on Indonesian children language, and her research interests are language variation, bi- and multilingualism, pragmatics and discourse analysis.

HANS VAN DE VELDE obtained his PhD in linguistics at Radboud University Nijmegen, The Netherlands (1996). He was lecturer in Dutch at the Université Libre de Bruxelles (1997-2002) and senior lecturer in sociolinguistics at Utrecht University (2002-2014). Currently, he is affiliated to the Fryske Akademy in Ljouwert (The Netherlands), as a senior researcher. His research areas are language variation and change, sociophonetics, (de) standardization, multilingualism, and minority languages. Recent papers include "Will Dutch become Flemish?" (Multilingua 2010: 385-416) and "The impact of formant measurements methods on identifying the speaker's regional origin" (Language Variation and Change 2014: 247-272). 
MARTIN EVERAERT took his PhD at Utrecht University, The Netherlands with a study on comparative anaphoric strategies in several Germanic and Romance languages. He is Professor of Linguistics and acting director of the Institute of Dutch Lexicology (INL). He works, primarily on the syntax-semantics interface (anaphora: reflexives, reciprocals), and the lexicon-syntax interface (idioms/collocations, and argument structure). His books include Birdsong, speech and language; Converging mechanisms, MIT Press (co-edited with John Bolhuis, 2013), The Theta system; Argument structure and the lexicon-syntax interface, Oxford University Press (co-edited with M. Marelj, T. Siloni, 2012), The Blackwell Companion to Syntax, I-V, Wiley-Blackwell (co-edited with H. van Riemsdijk, 2006). He is, among others, on the editorial boards of Linguistic Inquiry (MIT Press) and the Journal of Comparative Germanic Linguistics (Springer). 